\title{
Television and National Identity: An Ethnography of Television Audience in the Border of Indonesia-Malaysia
}

\author{
Rizki Briandana \\ Faculty of Communication Science, Universitas Mercu Buana \\ (email: rizki.briandana@mercubuana.ac.id)
}

\begin{abstract}
Television has a strategic position in constructing national identity. As part of the everyday life of the community, television provides a community-driven medium to construct its identity. In relation to the existence of mass media in the community and the issue of forming a national identity, there are unique problems that exist in the Sebatik Island of the Indonesian and Malaysian frontiers. These Indonesian people have no access to the broadcasting media, especially television, from Indonesia. This situation has persisted for several years, so the citizens of Sebatik Island use television broadcasts from Malaysia as their primary source of media communication. This study aims to examine how the people of Sebatik Island construct their national identity through the Malaysian television programs they watch daily. The methodology used in this study is ethnography with data collection techniques through observation and interviews of eight informants in September 2017. The result shows that the "mixed national identity" of Sebatik society is influenced by various factors and one of them is Malaysian television. Malaysian television programs also play a role as a socialization agent, among with other agents such as the presence of the community, the country, the organization, the culture, and the ideology.
\end{abstract}

\section{Keywords:}

national identity; television; border; ethnography

\section{Introduction}

Media is one of the key elements in the life of a society that can be gained anywhere and become an integral part of the community experience (Kim, 2008); (Morissan, 2016). Gauntlett (2008) emphasized that media is a vital element of a society, as today's society lives in a world that places the media as a necessity to living a normal life. This requirement refers to the fulfillment of the basic needs of the community toward the media, namely information, education, and entertainment (McQuail, 2010). From the conceptual aspect, Rashid, Rahman, and Butt (2017) argue that people use the media in various ways for different needs (p. 35). This refers to community interpretation activities in which Brunsdon and
Morley (2005) point out that society can tap into the message and meaning obtained through television programs in order to understand the daily activities of their life. This is done by the community through a process of interpretation focused on their subjective experience in understanding any given phenomenon( $\mathrm{p}$. 211). In this interpretation process, people have the freedom to create meaning and act in accordance with the meaning created through their understanding of the content displayed by the media (Halkoaho, 2012).

Basically, the image and meaning of national identity and culture displayed through television broadcasts are valuable assets in the process of forming and developing community identity (Rashid et al., 2017). Hence, the mass 
media plays an important role in uniting nations to help nurture the various elements that exist within society to ensure the integrity of a nation (Mcmillin, 2016).

Public broadcasting has become one of the important issues that arose related to discussions about the border areas of Indonesia (Yusuf, 2015). The Chairperson of the Indonesian Broadcasting Commission stated that there was a problem with uneven information needs, especially for people residing in those border areas(Riyanto, 2012). Until now, both information and entertainment in the border area was dominated by broadcasting institutions from neighboring countries (Widiastuti, 2016).

Among the problems of public broadcasting that have occurred in various border areas throughout Indonesia, Sebatik Island is an area that requires a great urgency to pay attention to (Widiastuti, 2016). This is related to the fact that there are villages that have absolutely no access to Indonesian television broadcasts (Riza, 2014). The television programs watched by Indonesians in the Sebatik border area are from Malaysia, the specific Malaysian television channels accessible to that community being TV1, TV2, and TV3 (Marti, 2013; Riza, 2014). Meanwhile, the Malaysian television channels made available to the Sebatik people are Malaysia's primary television channels with high viewership rates (Chong Lee, 2014). Rofil, Syed, and Hamzah (2016) stated that Malaysia's media, particularly television and radio, is rich with content related to Malaysia's national identity (p. 45). This is because Malaysian broadcasting policies are established to ensure public and private television programs aimed at strengthening local identity and culture (Latif, Mahmud, \& Salman, 2013; Rahim \& Pawanteh, 2010). In addition, television in Malaysia plays a large role in the process of establishing local cultural identity (Rofil et al., 2015, p. 62). Thus, the idiosyncratic identity in
Malaysian television programs are rich with ideas related to Malaysia's national identity (Chong Lee, 2014).

According to Anderson (2006), national identity is developed through various forms of communication. As Barker (2008) pointed out, the media encourages viewers to imagine an event by crossing the boundaries of time and space in order to pose the concept of race and nation through the media content shown.

Identity is not static, but dynamic. Identity is something that needs to be built, formed, and renewed continuously (Mulyana, 2017, p. 58). Identity formation involves the relationship between authorities that refers to the authority that establishes the construction of the social relationship. Anderson (2006) also argues that national identity is constructed intrinsically through various forms of communication, and the role of the media is important in building the social identity of a person or social group, especially in regard to race. Through this lens, the media is seen as the construction agent and the reality of the media is the reality built in an effort to fulfill various interests (Barker, 2003).

In today's modern era, the media plays a major role in every social dimension of society. Thus, a social analysis of modern society always involves the analysis of media's roles in the social interaction processes. In this context, mass media plays an important role in constructing of national identity. Seiter, Borchers, Kreutzner, and Warth (2013) stated that the development of national identity cannot be well understood without taking communication into account. In relation to the role of communication, television-viewing practices can be regarded as routine activities performed by one person on a regular basis. Watching television is one of the norms of daily life nowadays (Kim, 2008b). Consequently, television usage has been classified as a daily routine of community life, and the use of which creates special patterns that move dynamically in everyday life of society. 
To understand the relationship between the audience and television media in the Sebatik region, particularly in relation to the construction of national identity, the study of audience and media interaction should be carried out naturally. This research is in line with Kitley's (2000) thinking that emphasizes the importance of understanding the context of watching television, where the physical and social space of the subjects can form special patterns in building national identity. There is an interest in studying the construction of national identity, as the identity and image of Sebatik's society must be understood in a wider context by taking into account the role of television content in affecting the process.

Based on this background, the purpose of this study is to analyze how the Sebatik community constructs their national identity through Malaysian television.

\section{Methods}

This study uses an audience ethnographic method that implements interviews and observations as data collection techniques. The observation method is used to analyze activity and routine in television usage. Meanwhile, interviews were used to analyze the construction of national identity through the Malaysian television programs that were watched daily.

The collected data will be analyzed descriptively and inductively demonstrated by using open coding, selective coding, and axial coding (Benaquisto \& Given, 2008). Data processing will conclude by combining the results of various data collection techniques from multiple sources.

Data collection is focused on the issue of national identity for the Sebatik Island community as part of the Indonesian community with special circumstances. This unique situation encourages the formation of a community that has different characteristics and identities apart from other communities in Indonesia.
Researchers used the constructivism paradigm, hence the purpose of theoretical development in this paradigm is to produce evidence, perspectives, and explanations of certain social events so that researchers are able to reveal the interpretation and understanding system in the social environment (Jankowski \& Jensen, 2002).

\section{Ethnography Audience}

This research uses the ethnographic method of the audience. Pastina (2004) states that an audience's ethnography is based on fieldwork and data collection practices; data analysis is performed simultaneously ( $p$. 87) .

This approach involves observations into the interaction process using the media and it invites the audience to openly talk about its role as much as possible. The research was conducted from September to December 2017, and the goal was to document the activities of the subject's subject matter and understand the viewing experience from their own perspective. In addition, this approach also aims to conceptualize the conduct of the subject of the perpetrator as an expression of a particular social context. The main strengths of ethnographic approaches are the contextual understanding of the relationship between the different aspects of the observed phenomena (Jankowski \& Jensen, 2002). The researchers conducted an in-depth analysis of the viewing experience as an effort to understand why and how the citizens watch television in their daily lives.

In this research, the involvement of researchers is active participation in the lives of the informant's family. Through this observation, investigators can participate in routine subjects by researching what they are doing, listening to what they say, and asking others near the informant over a certain period of time (Mulyana, 2008). 
Figure 1.

Sebatik Island, Border Indonesia-Malaysia

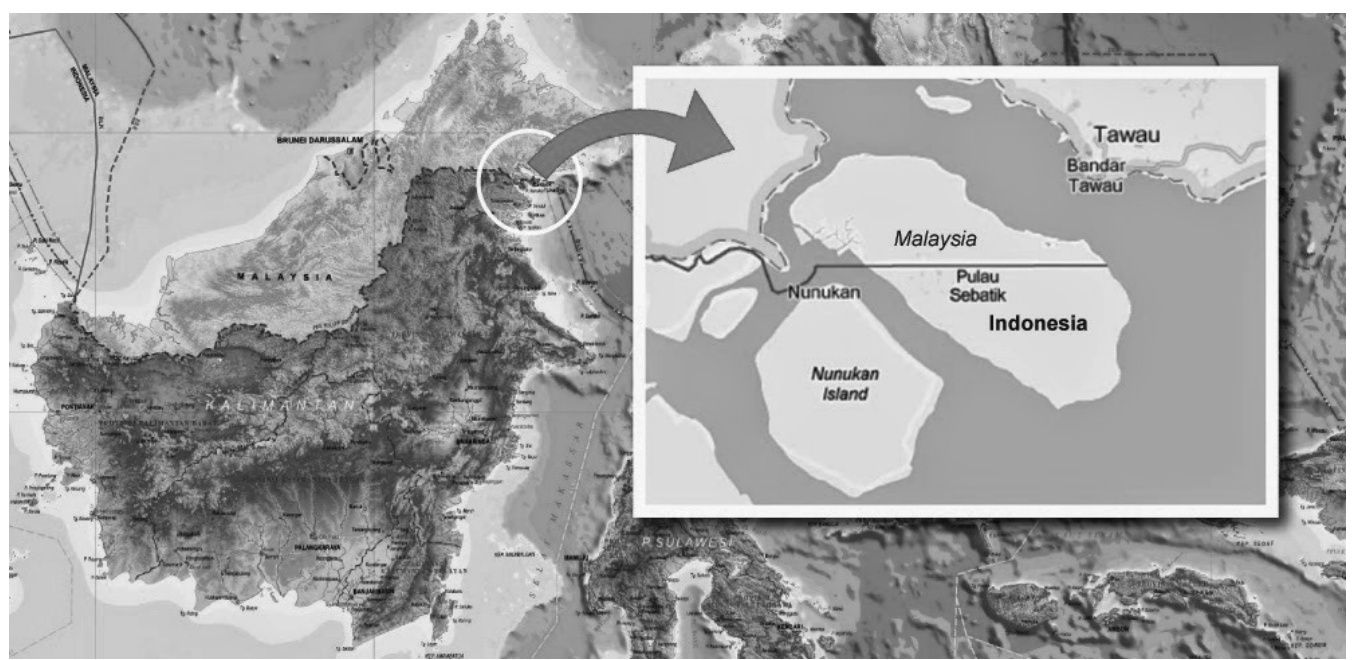

Source: Profile and dynamics of broadcasting in border areas (Riyanto, 2012).

\section{Research Subject}

The location and subject of this study was conducted on Sebatik Island, North Kalimantan. Sebatik Island is the outlying island in Indonesia adjacent to Malaysia. The uniqueness of Sebatik Island is that this island is owned by two countries; Indonesia in the south and Malaysia in the north.

Figure 1 shows the location of the study located in the Sebatik Island region, North Borneo, the area adjacent to the Malaysian state in the Sebatik Tengah region. In this study, the sampling process will focus on three villages: Maspul, Sungai Limau and Bukit Harapan. The justification for the selection of these three villages was that these three villages did not have access to Indonesian television for a long period of time.

\section{Primary Data}

This study uses two data collection techniques, namely observation and interview. Observation is observation through participant observation, while engagement observation refers to a process that requires social interaction between the researcher and the subject of the assessment. This interaction aims to find data systematically (Watson \& Till,
2010). Observation methods are particularly suited to investigate the process of building a national identity of the audience and televisionwatching activities. Participation observation is done by being together with the subjects being studied and performing the assignment with them (Lindlof \& Taylor, 2011). Meanwhile, there are 8 interview informants representing their respective villages in Sebatik Tengah area in this study.

The focus of this study is on the community representing the three villages in Sebatik Tengah (Maspul, Bukit Harapan, and Sungai Limau). Informant selection is based on the following criteria:

a. Informants are Indonesian citizens and part of Sebatik Island society in North Kalimantan.

b. Informants who have no access to Indonesian television broadcasts.

c. Informants have Malaysian television access.

d. Informants have watched Malaysian television programs for a long time (minimum 2 years).

After determining the criteria for the informants, the researcher conducted a pre- 
eliminary study to obtain informants who met the specified criteria. This pre-eliminary study includes 1) collecting data from the Village Head to find out residential areas that do not have access to Indonesian television broadcasts, and 2) brief door-to-door interviews with residents recommended by the Village Head's data.

\section{Results}

The people in Sebatik have to spend a lot of money on obtaining public broadcasts from Indonesia. For many years the Sebatik community has had no access Indonesian television broadcasts. This difficulty is due to the lack of facilities and infrastructure that the government should have provided. Referring to Indonesian Law No. 32/2 Year 2002 on Broadcasting, broadcasting in Indonesia must be carried out with the principle of fairness and equality for all Indonesian people. Moreover, the media needs to consist of information sources, entertainment, and education.

Aside from the lack of Indonesian television broadcasting access in Sebatik, the geographical position and the power of broadcast emissions from Malaysia enabled the people of Sebatik to be loyal audiences for Malaysian television programs.

Based on the observation data it can be concluded that television is part of the daily life of Sebatik society. Watching Malaysian television is one of the daily routine activities that can be seen almost in every home on Sebatik Island. In more detail, television-viewing practices among Sebatik Island communities can be seen through five indicators. According to Andrejevic (2008), television watching consists of (1) internal and external motivation, (2) television viewing time, (3) frequency of television watching, (4) attitudes, and (5) interest (cognitive process).

First, internal and external motivation refers to what motivates a person to watch television (Stockmann, 2016). In general, one's inner motivation for watching television is to get information, entertainment, or educational resources. These three things are also said to be the main motivation of the Sebatik Island community. Interestingly enough, in the absence of limited access to the media, Sebatik society is very interested in Malaysian media. This attraction is also driven by external motivations related to the dependence of the Sebatik Island community on Malaysia to various aspects of their lives.

Furthermore, this dependence encourages them to have sufficient knowledge and resources in interacting with the Malaysian community. Through Malaysian television broadcasts, the Sebatik community feels that their need for such knowledge can be met. In addition, the motivation for watching Malaysian television broadcasts was also intended to make the broadcast a social reference.

Second, the duration refers to the time spent watching television. In this study, the duration of television viewing was identified based on them observations made of the Sebatik Island community. The findings showed that the Sebatik community spent 8 to 10 hours a day watching Malaysian television. This activity is divided into three main times: in the morning between $8 \mathrm{am}$ to $12 \mathrm{pm}$, which is usually dominated by women. Children who are just coming back from school and watching television from 2 to $5 \mathrm{pm}$ dominate the afternoon session. In the evening session, from 6 to $10 \mathrm{pm}$, the head of the family normally controls what the family watches.

Based on the three main times for watching television shows, each family member has their own program options. Generally, the most engaging program for adults is drama, news, and religious programs. For example, the most popular drama programs on Sebatik Island are "SebenarnyaSayaBukanIsteriDia", "Bibik-Bibiku", "Lara Terindah", "Akasia”, "Samarinda", and "Tiga Hari Menanti Mati". For news programs, most informants watch 
the news show called "BulletinUtama". Meanwhile, the programs that children are interested in are cartoon programs such as "Upin-Ipin”, "BoBoiBoy", and "Ejen Ali".

Sebatik's favorite television programs vary by age and gender, especially in the family context. This distinction provides an overview of how Malaysian television broadcasting gets its place in the hearts of the audience and meets the viewing needs of the Sebatik community.

Third, the frequency of watching television refers to the frequency of how often the Sebatik Island community watches Malaysian television programs. Based on field data it was found that the Sebatik community watches Malaysian television daily and this activity is part of their routine activities. This routine has been practiced for many years. Most Sebatik Island people have watched Malaysian television shows since childhood and have a viewing experience that cannot be extinguished from their memory even when they become adults. This finding is in line with Morley (1992) which states that television watching is a routine activity that fills everyday life and is done throughout the day (p. 47). The practice of watching television is one of the routines in the daily activities performed (Morley, 1992). Therefore, television watching becomes a cultural practice covering the scope of time and space for the Sebatik community.

The high frequency of watching Malaysian television for the Sebatik community made them more knowledgeable about Malaysia. This is evident from the results of the study showing the vast knowledge of the Sebatik Island society on the development of Malaysia in terms of economic, political, social, and cultural ideals as compared to the development of their own country of origin, Indonesia.

Fourth is attitude. Attitude in this study refers to the attitude of the Sebatik community toward the Malaysian television program. This attitude can move towards the positive or negative (Andrejevic, 2008). The findings show that most of the people of Sebatik have a positive attitude toward the Malaysian television shows they watch. This positive attitude relates to the role played by Malaysian television broadcasts that cater to the needs of the Sebatik community as a source of entertainment, information, and education. Additionally, this positive attitude is also a major factor affecting the acceptance of the Sebatik community in terms of the various meanings and values in each television program they watch every day.

Fifth is interest. In this context, interest can be seen from two different perspectives. The first perspective is to look at interest as a pull factor for one to observe the response to a particular object (Rofil et al., 2016). The second perspective evaluates interest as a result of an increasingly rewarding experience by individuals (Rofil et al., 2016).

In the context of the Sebatik community, watching TV programs in their everyday life refers to the second perspective of interest. This is because the activity is seen as a product built through the Malaysian television viewing process. The Sebatik community has much interest in the various messages, themes, and values in the programs they watch every day. The interest arising from watching television was due to the positive attitude of the community toward Malaysian television programs. Therefore, interest in television viewing among the people of Sebatik Island serves as a cultural practice that is within the scope of both time and space. Television viewing activities have led to further interaction between Sebatik society and Malaysian television programs. Specifically the television-watching activity caused the people of Sebatik to make Malaysian television shows watched as their daily guide for life. These include cultural, social, economic, and political aspects.

Based on the results of the study, informants give the names of actors/figures they are interested in Malaysian television program, such as Izzue Islam, Adi Putra, Maya 
Karin, P Ramlee, Rosyam Nor, Siti Nurhaliza, Safiq Rahim, Safee Sali, Ustaz Kazim Elias, Azli Khairi , Razali, and Kamarudin Mape. Each of these figures represents the various values and roles associated with the values of Malaysia's national identity. The findings are consistent with the study conducted by Ang (2013), which states that television watch routines can create interest in a person and thus the figure is used as reference for the daily life of Sebatik society.

Entertainment programs, news, and information related to social, political, economic upheaval of Malaysian culture make Sebatik people more aware of the current development of Malaysia compared to the development of Indonesia. In addition, the Sebatik community found that Malaysian television broadcasts were interesting and that they encouraged the formation of psychological and emotional relationships with Malaysia.

The admission of other countries to the Sebatik community is not eliminating their desire to access Indonesian broadcasts. Informants also say they want to know the developments in their own country. The informant states:

"70\% in Maspul village watching Malaysian television programs. So $30 \%$ is just the middle class and above who can watch Indonesian broadcasts. We cannot watch Indonesian TV channel, we honestly want to watch Indonesian TV," (Agus, personal communication, October 4, 2017).

"Information about Indonesia we did not get through by the media, but through discussions at the village office," (Sarifudin, personal communication, October 5, 2017).

"We really miss the Indonesian TV channel, because we want to know how the development of Indonesia. If I want to watch Indonesian TV broadcasts just sit in a neighbor's parabola house," (Sabarina, personal communication, October 4, 2017).

Lack of access to Indonesian television caused the Sebatik community to watch Malaysian television as the premier television broadcasting option for a long period of time. The practice of watching foreign television encourages societies to form different views regarding the content they watch in their daily lives, whether the genre of the show is in the form of a drama, reality TV, news, or other Malaysian program content.

According to informants, the daily routine of the use of this media has been interesting to note. Among the things they get is that they can positively accept the values found in every Malaysian television program they watch. This is in line with the opinion expressed by the informants.

"I like watching drama, cooking, and religious programs. The majorities are all good. I do not know about Indonesian television, because I never watched," (Ira, personal communication, October 5, 2017).

"For me the Malaysian television program is better than Indonesia, although at home I've been using parabolic antenna, but every day I always watch Malaysian television," (Darman, personal communication, October, 5 2017).

"I have never watched the broadcast of Indonesia, so for me Malaysian television is very good and I really enjoy it," (Yoswes Wasi, personal communication, October 6, 2017).

"The most interesting of Malaysian television broadcasts are their language, actors, and social life. Life is good, good roads, nice cars, nice house. We are so glad to watch it.I like to watch news on Malaysian television. I also support the UMNO 
and Barisan Nasional parties," (Suisno, personal communication, October 4, 2017).

When interpreting Malaysian television programs, the Sebatik community enjoys television content as a perfect social picture of life. This is because television viewing is considered far better than the reality of real society. In addition, based on the informants, Malaysian television attracts the audience's emotions when they saw a sad or happy show. This shows the dynamics of Malaysian television program, as the informants can feel the emotional impact of watching. Some informants have stated that watching is an entertainment platform for the public as added information and personal satisfaction when discussing ongoing television shows or after the television program is over. The preferred television programs are then the subject of informal discussions with family members and friends. In this regard, broadcast media, particularly Malaysian television, plays a large part in education, entertainment, and information dissemination. Based on the opinion of informants on information obtained from television, the information is used as a reference in carrying out daily life activities.

"I heard Negaraku national anthems every day through Malaysian television, if Indonesia Raya song I never heard, except for events in the sub district" (Mardin, personal communication, October 7, 2017).

"I always watch Malaysian news, so I know Malaysian leaders, if Indonesian leaders really do not know," (Asma, personal communication, October 5, 2017).

"Malaysian history I know of Mahatir Muhammad who was the first leader. Along with the good actor P-Ramlee, I have seen from the Malaysian documentary. I usually watched through a documentary program,"(Yoswes Wasi, personal communication, October 6, 2017).

"Songs in many Malaysian dramas I memorize. If Indonesian song I do not know. Otai song, for example Awi, 'where did it disappear' was a dream... the mystery of the dream is it? 'Where did you disappear myself?' Otai songs also slam ya, from Zamani,"(Suisno, personal communication, October 4, 2017).

"Regarding the currencies, in fact society is using the ringgit because it is used in their daily lives. With the practice of watching Malaysian TV broadcasting using the ringgit so we are using the ringgit," (Sarifudin, personal communication, October 5, 2017).

The Sebatik community understands that the television programs they watch bring up concepts of Malaysia's national identity and that these values can shape their own identity.

This is explained through the following quotes: "I see that television has a role in shaping the identity of the society as they watch Malaysian television every day,"(Mardin, personal communication, October 7, 2017).

“Television plays an important role in shaping a person's character. The present values are not the absolute hegemony of Indonesia. On the other hand, these values are the result of interventions from Malaysian television broadcasts that shape the behavior of society in Sebatik," (Abdul Salman, personal communication, October 6, 2017).

Based on the findings it can be concluded that the broadcasting situation in Sebatik is less interfering than the Indonesian government. Therefore, there are many values of Indonesia's 
national identity that are not understood by the Sebatik community. On the other hand, the people of Sebatik use television from Malaysia so that Malaysia's national identity values are bestowed on them. Television media should serve as a social institution that can be used as a reference for the people living on Sebatik Island, especially in defining who they are.

\section{Discussion}

\section{Malaysia Television Programs in Sebatik Daily Life}

The results show that the Sebatik community enjoyed the television programs being watched. For them, the enjoyment of watching television is entertainment and a key source of information for them. In addition, the people of Sebatik enjoy discussing the content of current television programs they have just watched. This coincides with Gray's (2012, p. 256) statement which clarifies that an important part of television watching is the content that is watched throughout the day. For informants, watching television is not a passive process. They do not just sit quietly in front of the television and receive everything that is delivered on television alone. An audience can also choose to engage in discussions related to the content of the television being watched. In these discussions, they discussed issues that are being communicated through television, whether it is the latest news, the characters of a drama, or politics. The content of the television program was then a source of discussion among informants. An analysis of the findings shows that there are informants who discuss the television content they are watching. For example, informants discussed Malaysian television content such as kidnapping news by the Abu Sayyaf group, political conflicts, and the plot of the drama "Bibik-bibiku". In the discussion it was found that informants did not directly touch upon matters relating to the Indonesian state.

Interaction between audience and television is a social dynamic revealing that these interactions are often linked to their daily situation. Based on these findings, it was found that television text plays an important role in the social life of the Sebatik community. This finding supports the study of Morley (2003), who states that television content is interpreted by informants according to their own priorities (p. 201). In this study, informants stated that the information obtained from watching television shows was used as reproduction material when socializing with the community. As the only television broadcast of choice for the people in Sebatik, it was found that Malaysian television programs had fulfilled their need as an information channel. In addition, Malaysian television also cater to their entertainment and education needs. In short, the Sebatik community has a high dependence on Malaysian television channels because the Sebatik community has long been watching Malaysian television. However, as an active audience, the Sebatik community still has control over content selection and how they benefit from the information they receive.

From the various meanings and values contained within each television program watched, the people of Sebatik can choose the meaning and value they receive, and they can even negotiate to adapt it to their situation as a border community. Thus, this media interpretation process refers to Fish's (2004) concept that states that there is no true and absolute interpretation. According to Fish (2004), that interpretation is not objective or socially vacated. The meanings of a person are often related to the social or community context in which they live in and are not from the outside. Fish (2004) also states a concept of interpretive and translation communities that are part of the community after agreement is reached on a construction (p. 167). Similarly, the way in which the community lives is actually not a reflection of the reality outside the community but a construction that is formed based on the consensus of the reality 
they experience and it remains strong so long as the community remains confident of it. This is in line with Iser (2012), who emphasizes the hermeneutic process as "The Act of Reading" in the process of producing meaning. In this process of interpretation, people who are actively involved in the process give meaning to a text through the process of interpretation which goes on continuously. This process is formed through the result of interaction between the text and the reader. The views of Iser (2012) and Fish (2004) are based on the existence of differences between the world and culture owned by the Sebatik community with Malaysian television content makers.

The process of interpretation is seen as a unique process and is a major focus that can be holistically analyzed. Watching television programs is not about the impact that the mass media can have on them, it's about the meaning formed through the interactions that occur between television content and the audience. In the context of the interaction between the Sebatik society and the Malaysian television program, the community has made Malaysia watch television activities as a routine activity for a long time. This is evidenced by the findings from various studies showing that the Sebatik community is fond of the social life displayed in Malaysian television, as informants feel close to the culture displayed on the television broadcast. In addition, most informants also emotionally enjoyed watching scenes in a sad or happy Malaysian drama. For children who watch Malaysian television broadcasts, they were found to be using a lot of terms used in the cartoon programs they watch on Malaysian television. This is evident by the observation that the word used by young children in Sebatik is based on the dialogue of Malaysian cartoons, such as "betul..betul.. betul.." in the cartoon "Upin-Ipin" or "bo..bo.. boy" from the cartoon "Boboboy".

In addition, the analysis results also shows social and cultural activity among the audience where the Sebatik community takes in the meaning of the programs they watch. The findings show that informants love and have a positive view of Malaysian television. They also practice much of what television has brought into their lives. This finding is in line with Triwardani (2013), which proves that the interaction between television and society produces various forms of social and cultural activities; for example, the use of the Ringgit currency in the economic activity of the Sebatik community. Although the people of Sebatik have a good understanding of Malaysia's information and development, they do not know of the developments of their own country. These television-watching activities are their way to "escape" from the reality of their lives. In other words, everything displayed on television makes the Sebatik community forget about the problems they face by envisioning the luxurious and perfect life they watch on television.

The results of the analysis on the drama program by the audience show a sense of emotion (emotional tone) such as the joy, pride, sadness, or anger caused by the scenes shown in the drama program. In this context, when a person is touched by his/her emotions due to watching a drama, the audience has reached a level of deep emotion. This deep emotional level is one of the forms of expression in one's psychological aspect when they know something with feelings (Bignell \& Lacey, 2014). This emotional atmosphere is also parallel to Ang's (2013), concept stating that viewers can be emotional because there is a strong linkage between the program's content and the audience (p. 179). The Sebatik community can be recognized as a loyal Malaysian audience because they can deeply relate to the content presented in the drama.

In regard to news programs, political content is one of the aspects expressed by informants. As a source of community civic participation, informants' knowledge of linking Malaysian political issues to economicpolitical factors has helped their social activities (Livingstone \& Markham, 2008, p. 360). In 
addition, some informants have also expressed support for the UMNO and Barisan Nasional parties. This support is highlighted through their positive outlook on UMNO political party leaders and Barisan Nasional, which are featured in Malaysian television news. This suggests that the attention and interest of informants to Malaysian politics is very high. Although the Sebatik Island community does not have the right to vote in elections in Malaysia or be involved further in their political decisions, they are still willing to reach the level of support for the political parties in Malaysia.

The analysis results show how informants use television-viewing experiences to build their national identity. The activity of watching the Malaysian television program studied in this research is an exploration to seek a more in-depth understanding of the construction of a national identity. This also supports the study of Morley (2003), which states that television can be seen as a technology integrated into the construction of the practice of daily life in a society.

\section{Construction of National Identity}

The results of the analysis show that Malaysian television is a powerful social agent in the construction of a national identity. The influence of this media led the Sebatik community as an audience who was interested in programs, figures, and cultural products derived from Malaysia. The social construction process that takes place in this situation takes a long time and is done so slowly. As a social agent, Malaysian television offers a variety of values and characteristics that are very similar to the national identity of Malaysia. Generally, mass media content, especially Malaysian television, is planned and produced with strong national identity characteristics with the aim of disseminating national ideology for Malaysian society (Rofil et al., 2016).

Referring to this analysis, this study is an essential basis for understanding and identifying the construction process of the national identity of the Sebatik community. This is demonstrated in Figure 2.

The construction of the national identity of the Sebatik community was done in four stages. First, there is the construction process that goes through television broadcasts. At this stage, the Sebatik community was able to use the interpretation of television content viewed as a reference in forming their attitudes and

Figure 2.

National Identity Construction of the Sebatik Community

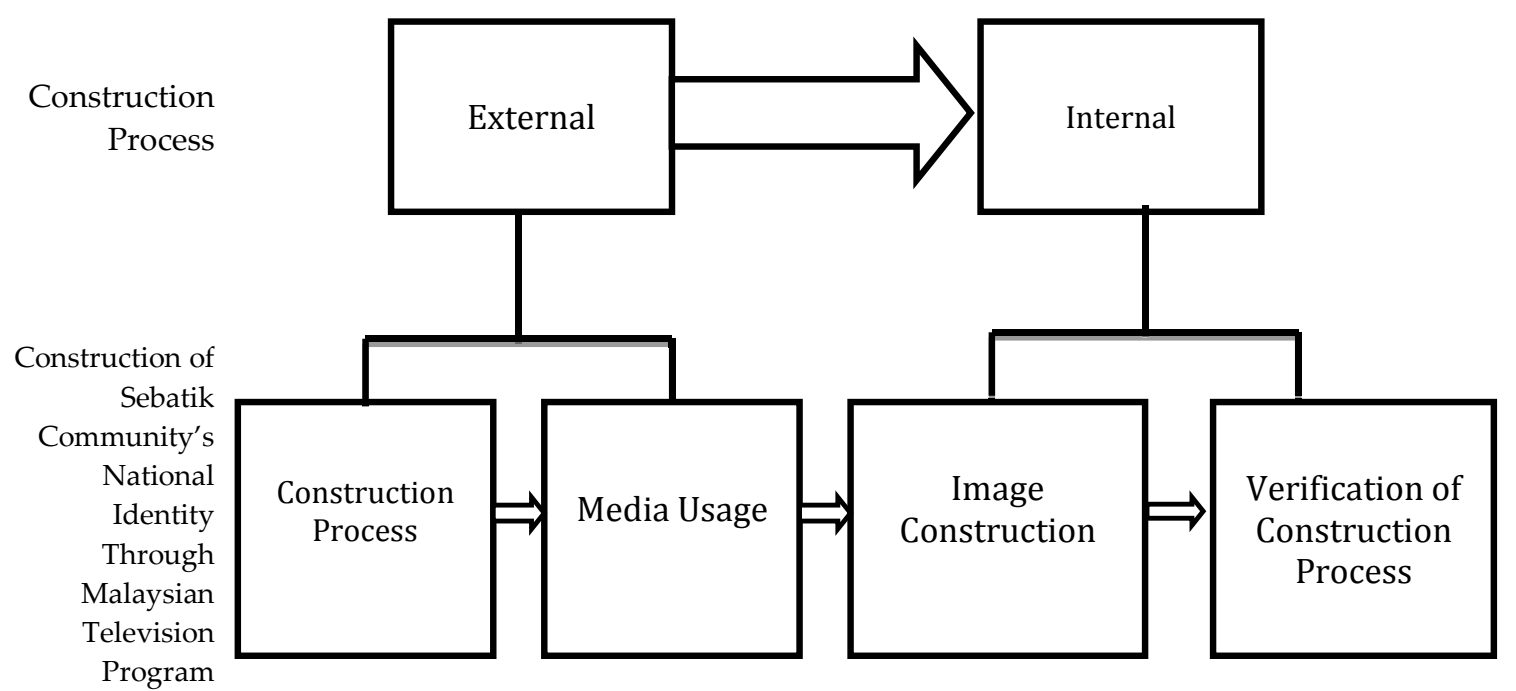

Source: Based on research findings. 
behaviors. Secondly, the use of mass media is the main choice. At this stage, the Sebatik community makes Malaysian television the only choice in media use. Third is image construction. At this stage, the image formed through the Malaysian television broadcasts process is likely to be positive. In general, there is perception of the Sebatik community that the portrayal of life displayed in Malaysian television programs is an ideal form of life. Fourth is the verification of the construction process. At this stage, the people of Sebatik participated and were willing to engage in the process of constructing a national identity. This process involves viewing Malaysian television broadcasts with the perception that Malaysian television broadcasts are able to meet their needs for information, entertainment, education, and role as a source of discussion information in interacting with the Malaysian community.

The construction process of the national identity of the Sebatik community involves the role of Malaysian television in their daily lives. As part of Sebatik's daily life, television plays an important role in every social dimension of society where Malaysian television is used as a major source of reference in constructing the national identity of the Sebatik society.

The Malaysia television channels that exist in the private space of the Sebatic community allows for the construction process to take place in a more personal context. Thus, the interpretation of the national identity values found in Malaysian television broadcasts is also shared with fellow family members through the television-watching activities and discussions that occur amongst themselves during the watch routine. This highlights the important role of television in the construction of their national identity even more so when the Sebatik society chooses to use their interpretation as an interaction reference in the social world.

These four processes led to the formation of the unique identity of the Sebatik society.
This unique national identity refers to the existence of mixed cultures between Indonesian and Malaysian ideals, such as the use of mixed language among the original ethnic languages of Indonesia (Java, Bugis and Flores) with Bahasa Malaysia. Secondly, there is the use of Malaysian cultural products such as clothing and media, such as television shows and popular songs. Third is the understanding of Malaysian symbols, such as Ringgit currency, the national anthem "Negaraku", Malaysia's flag, recent political issues, and products made in Malaysia.

\section{Conclusion}

This study demonstrated that identity construction needs to be understood by looking at one's daily experience. This is because an individual interprets messages based on their social experience. The national identity of the Sebatik society is uniquely constructed through their daily lives influenced by various factors, namely; (1) geographical location, (2) economic activity, (3) social-cultural equality, (4) lack of references regarding the national identity of Indonesia, and (5) television as the main source of reference. All of these factors indicate that television is not the only factor affecting the construction process of the national identity of the Sebatik society. However, if studied more closely, the role of Malaysian television program on the Sebatik community is "the main point" in the process of forming a national identity for every individual. The mass media that existed in the society of Sebatik also played a role as an agent of socialization along with other agents, such as the presence of society, state, organization, culture, and ideology.

The audience's perspective toward mass media as a socialization agent is an important element to be examined as the media content of Sebatik carries the national identity of a foreign country; Malaysia. This situation becomes more challenging when socialization agencies in Indonesia, such as education departments and 
government organizations, do not play their proper role in building Indonesian identity.

\section{Reference}

Anderson, B. (2006). Imagined communities: Reflections on the origin and spread of nationalism. London: Verso Books.

Andrejevic, M. (2008). Watching television without pity: The productivity of online fans. Television \& New Media, 9(1), 24-46. doi: 10.1177/1527476407307241.

Ang, I. (2013). Watching Dallas: Soap opera and the melodramatic imagination. London: Routledge.

Barker, C. (2003). Cultural studies: Theory and practice. Las Vegas: Sage.

Bignell, J., \& Lacey, S. (2014). British television drama: past, present and future. London: Springer.

Benaquisto, L., \& Given, L. (2008). The encyclopedia of qualitative research methods. New York: Sage.

Brunsdon, C., \& Morley, D. (2005). The Nationwide Television Studies. London and New York: Routledge.

Chong Lee, Y. (2014). Berita televisyen dan kebebasan media di Malaysia: Suatu kajian terhadap berita televisyen Bahasa Inggeris TV2 dan NTV7. Jurnal Komunikasi; Malaysian Journal of Communication, 30(2), 141-158. doi: 10.17576/JKMJC-2014-3002-08

Fish, S. (2004). Postmodern Sophistry: Stanley Fish and the Critical Enterprise. New York: SUNY Press.

Gauntlett, D. (2008). Media, gender and identity. New York and London: Routledge.

Gray, J. (2012). Watching with The Simpsons: Television, parody, and intertextuality. London: Routledge.

Halkoaho, J. (2012). Identity-related media consumption: a focus on consumers' relationships with their favorite TV programs. Helsinki: Vaasan yliopisto.

Marti, E. (2013). Eksistensi lembaga penyiaran publik radio Republik Indonesia Entikong dalam upaya meningkatkan wawasan kebangsaan masyarakat perbatasan Entikong Kalimantan Barat dan warga Indonesia di Tebedu Malaysia. Jurnal Program Magister Ilmu Sosial Universitas Tanjungpura, 1(1).

Iser, W. (2012). Interaction between text and reader: Wolfgang Iser. In J. Collins \& A. Nisber (Eds.), Theatre and performance design (pp. 343-347). London: Routledge.

Jankowski, N. W., \& Jensen, K. B. (2002). A handbook of qualitative methodologies for mass communication research. London: Routledge.

Kim, Y. (2008). Introduction: The media and Asian transformations. In Y. Kim (Ed.), Media consumption and everyday life in Asia (pp. 13-36). London: Routledge.

Kitley, P. (2000). Television, nation, and culture in Indonesia. Ohio University Center for International Studies.

La Pastina, A. C. (2004). Telenovela reception in Rural Brazil: Gendered readings and sexual mores. Critical Studies in Media Communication, 21(2), 162-181. doi: 10.1080/07393180410001688056.

Latif, R. A., Mahmud, W. A. W., \& Salman, A. (2013). A broadcasting history of Malaysia: Progress and shifts. Asian Social Science, 9(6), 50. doi: 10.5539/ass.v9n6p50

Lindlof, T. R., \& Taylor, B. C. (2011). Sensemaking: qualitative data analysis and interpretation. In T. R. Lindlof \& B. C. Taylor (Eds.), Qualitative Communication Research Methods: Third Edition (pp. 241-281). London: Routledge.

Livingstone, S., \& Markham, T. (2008). The contribution of media consumption to civic participation 1 . The British Journal of Sociology, 59(2), 351-371. doi: 10.1111/j.1468-4446.2008.00197.x

Mcmillin, D. C. (2016). Choosing commercial Television's identities in India: A reception analysis. Continuum, 4312. doi: 10.1080/10304310220121037 
McQuail, D. (2010). Mass communication theory. London and New York: Sage publications.

Morissan, M. (2016). The influence of politicians on television content in post-authoritarian Indonesia. Jurnal Ilmu Sosial dan Ilmu Politik, 20(3), 204-220. doi: 10.22146/ jsp.27205

Morley, D. (2003). Television, audiences and cultural studies. London and New York: Routledge.

Mulyana, A. (2017). Sekaten tradition: The ritual ceremony in Yogyakarta as acculturation reality of Javanese culture in Indonesia. International Journal of Humanities and Social Science Studies, IV(2), 50-61. doi: 10.29032/IJHSSS.v4.i2.2017.50-61

Mulyana, D. (2008). Metode penelitian kualitatif. Bandung: Remaja Rosdakarya.

Rahim, S. A., \& Pawanteh, L. (2010). The local content industry and cultural identity in Malaysia. Journal of Media and Communication Studies, 2(10), 215.

Rashid, K., Rahman, B. H., \& Butt, A. R. (2017). Journal of Media Studies Media Consumption and National Identity Formation of Adolescents in Pakistan. Journal of Media Studies, 32(1), 1-31. doi:10.1006/jado.1998.0201

Riyanto, M. (2012). Profile and dynamics of broadcasting in border areas. Jakarta.

Riza, F. (2014). KPID Kalimantan Barat siapkan roadmap informasi perbatasan. Retrieved April 6, 2016, from http://kalbar. antaranews.com/berita/323515/kpidkalbar-siapkan-road-map-informasiperbatasan.
Rofil, F., Syed, M. A., \& Hamzah, A. (2015). “Jadi Melayu": Televisyen dan pembentukan identiti wanita keturunan Jawa di Malaysia. Jurnal Komunikasi; Malaysian Journal of Communication, 31(1), 41-58. doi: 10.17576/JKMJC-2015-3101-03

Rofil, L., Syed, M., \& Hamzah, A. (2016). Studying a television audience in Malaysia: A practice of audience ethnography in Kampung Papitusulem, Sabak Bernam, Selangor. Pertanika Journal of Social Sciences \& Humanities, 24(3). doi: 10.1080/01419870.2015.1110611.6

Seiter, E., Borchers, H., Kreutzner, G., \& Warth, E.-M. (2013). Remote control: Television, audiences, and cultural power. London: Routledge.

Stockmann, D. (2016). One Size Doesn't Fit all: Measuring News Reception East and West. Chinese Journal of Communication, 4750. doi: 10.1080/17544750902826640

Triwardani, R. (2013). Etnografi Pemirsa dan Penggunaan Televisi dalam Keluarga. Jurnal Ilmu Komunikasi, 9(2). doi: 10.24002/ jik.v9i2.167

Watson, A., \& Till, K. E. (2010). Ethnography and participant observation. London: Sage Publications.

Widiastuti, N. (2016). Media Asing Serbu Wilayah Perbatasan. Retrieved May 2, 2016, from http://poskotanews. com/2015/09/04/dirut-rri-media-asingserbu-wilayah-perbatasan/

Yusuf, I. A. (2015). Radio di kawasan perbatasan Indonesia dalam centering the margin. Jurnal Ilmu Komunikasi, 12(2). doi: 10.24002/jik.v12i2.469 